\title{
Reactive Power Compensation of the Grid Connected PV System
}

\author{
${ }^{* 1}$ Vijaya Huchche, ${ }^{2}$ Prachi Salodkar, ${ }^{3}$ Pratik Manusmare \\ ${ }^{1,2,3}$ Shri Ramdeobaba College of Engineering and Management, Nagpur \\ Email: ${ }^{1}$ huchchev@rknec.edu, ${ }^{2}$ salodkarpa@rknec.edu, ${ }^{3}$ psmanusmare@gmail.com
}

Received: 06th October 2019, Accepted: 20th November 2019, Published: 31st December 2019

\begin{abstract}
Renewable energy has been a subject of research owing to the continuous environmental concerns across the globe. The overall power factor of the power systems is reduced due to DC energy fed to the grid using electronic energy inverters. Increased grid load due to poor power factor triggers losses in the grid. Active and reactive power can be produced by proper control of multistage inverters. Instantaneous reactive power theory enables the control of the active currents and reactive currents of the inverter by regulating the amplitude and phase angle of the inverter. This paper deals with the instantaneous reactive power theory by implementing the hysteresis current controller. The proposed control scheme consists of instantaneous reactive power theory (IRPT) based on the current source inverter (CSI) to suppress harmonic currents and reactive power compensation. Improvement of the power factor through compensation of the reactive power at an ideal level was attempted using the control system of grid-connected photovoltaic systems. The effectiveness of the proposed control strategy was implemented with the help of simulation using MATLAB/SIMULINK.
\end{abstract}

\section{Keywords}

Photo-Voltaic System, Power Quality, Instantaneous Reactive Power Theory, Reactive Power Compensation, PCC.

\section{Introduction}

Containing the stress of the main transmission systems using renewable energy is a topic most sought after by researchers. Employing photo-voltaic (PV) cell modules, harnessing solar power has become one of the most viable sources of renewable energy. The efficiency of the PV cells can be fully trapped under myriad situations of solar intensities and temperatures incorporating altered control system using MPPT technology. Conforming to the standard power quality norms is essential while integrating renewable energy sources into the grid. Power quality issues in a grid-connected solar PV system include:

- Supply side, viz. power factor, reactive power mitigation, voltage regulations, and

- Non-linear loads on the solar power harness assembly creating sags, swell or under voltage, over voltage and dynamic momentary fluctuations.

The above-mentioned issues cast significant effects on the performance and viability in power system devices $[1-4]$.

It is widely experienced that the inductive load in the distribution system causes lagging power factor and hence under voltage in the system. PV system operates at unity power factor. The injection of power with the PV system reduces the power factor. The poor power factor puts burden \& losses on the grid leading to utility charged the penalty to the end user. The inverter working as the voltage controller produces harmonics in the resultant voltage entering the grid resulting in to issues of standard power attributes. Mushrooming use of solar assemblies across industries will increase the concerns about power quality and its amelioration. Such issues need to be resolved by designing the proper control mechanism for the inverter in the PV assembly. Many power regulation algorithms are reported for the ideal transformation between active and reactive powers [5-9]. Generating establishments are bothered about the rising use of periodical renewable energy sources amongst users leading to poor power quality concerns. The present study involved instantaneous reactive power theory with the grid-interfacing inverter used for the effective performance of the important functions: shifting of active power tapped from the PV system and load reactive power demand support in case of the distribution system. Additionally, effective controlling grid-interfacing inverter, the PQ constraints at the PCC are strictly maintained. The sinusoidal signal integrator and instantaneous reactive power theory with hysteresis currentcontroller based current reference generator can be employed in the control design [10-15].

\section{Methodology}

A power electronic tool connected in shunt to the system is the Voltage Source Converter (VSC). The inverter active power is adjustable through the change of output voltage phase angle as per the theory of instantaneous power. Also, the inverter reactive power can be controlled by controlling the amplitude of its output voltage. With the help of the hysteresis controller, gate pulses are modulated for the inverter. Fig. 1 shows the proposed PV based distributed generation system with the grid. 


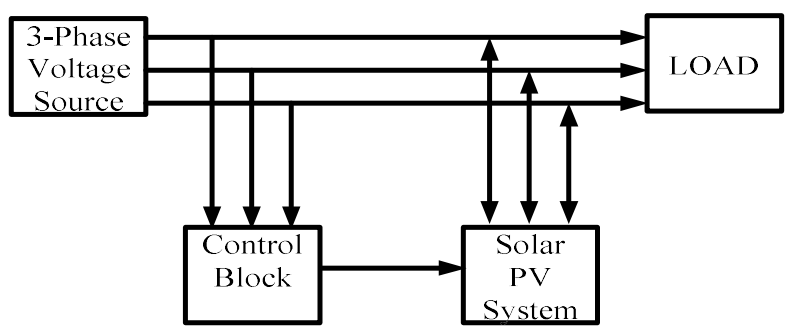

Fig.1: Outline Sketch of the Distribution Generation System

\section{Instantaneous Reactive Power Theory (IRPT):}

The IRP theory, initially proposed by H. Akagi to regulate active filters [5], relies on a set of instantaneous powers fixed in the time domain. This $p-q$ approach is valid for operation under all conditions namely transient and steady-state operation. This theory makes use of some famous transformation models like Clarke's Transformation. Here the voltage and current waveforms are sensed and then made to transform from a-b-c coordinates to $\alpha-\beta-0$ co-ordinates also known as the Clarke transformation. After this transformation, based on a certain set of equations calculate active and reactive power and then eliminate the power components having harmonics in it by passing through a certain suitable low pass filter of suitable frequency. This new set of power and already derived new voltages in a different coordinate namely $\alpha-\beta-0$ coordinates, we again find out the reference source current in this frame and then using inverse Clarke's Transformation we convert this reference source current again back to a-b-c coordinates. This new reference source current is then compared against actual sensed source current waveforms and the error is driven through a hysteresis controller with a certain band for getting different gate pulses for the operation of the inverter. The hysteresis controller limits are fixed to get the desired result. The hysteresis controller compares the observed and reference currents and operates the inverter as shown in Fig. 2.

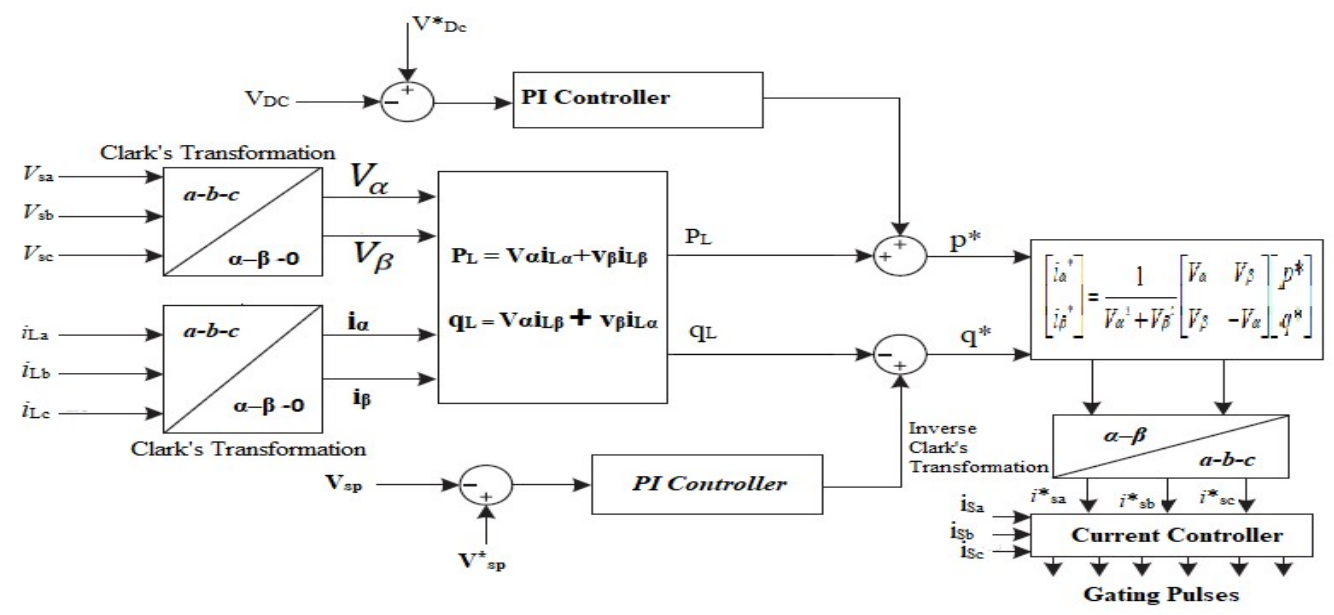

Fig.2: Block Diagram of IRP based Control Algorithm

\section{System Parameters}

Three-phase supply voltage: $415 \mathrm{~V}, 50 \mathrm{~Hz}$ (Stiff)

Load: 3-phase delta connected R-L load

$\mathbf{V}_{\mathrm{DC}}=700 \mathrm{~V}$

Interfacing Inductance: $\mathrm{L}=8.609 \mathrm{mH}$.

DC bus Capacitance: $\mathrm{C}_{\mathrm{DC}}=500 \mu \mathrm{F}$

SPWM switching frequency $=2.5 \mathrm{KHz}$

\section{Case Studies}

Conventional solar PV assemblies work at the unity power factor, irrespective of the reactive power demand of the load. When the solar PV system is connected to the grid, it shares active power, but at the same time reduces the power factor. The following cases describe the power quality problems especially, the power factor, reactive power compensation and hence voltage regulation in the grid-connected solar PV system. 
Case 1:

In the first case, we are having a simple grid-connected system to the R-L load with $25 \mathrm{KW}$ active power and 10 KVAR reactive power having 0.9285 lagging PF as shown in Fig. 3(a). The power triangle of the system is as in Fig. 3 (b).

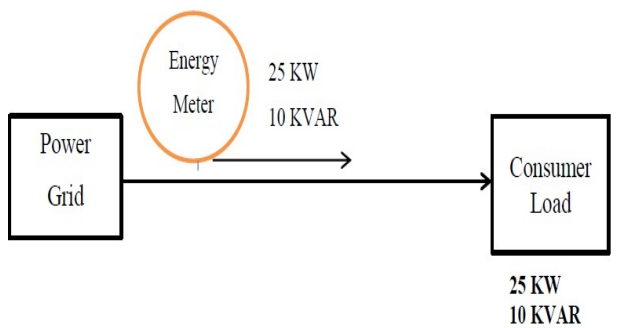

(a)

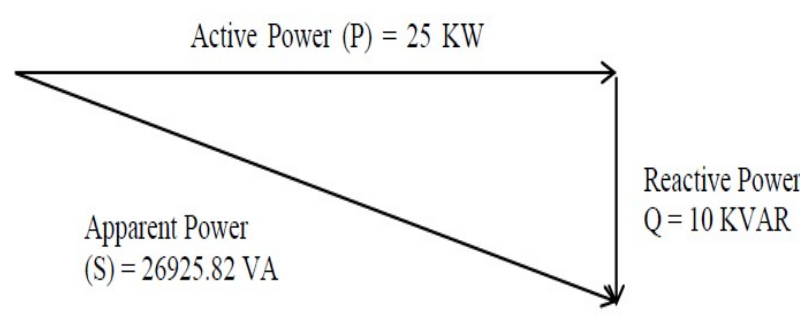

(b)

Fig.3: (a) Schematic of the General Power System with Load $\quad$ (b) Power Triangle

Case 2: $50 \%$ of the Load Sharing by the Grid Connected Solar PV

In Case 2, solar PV energy aids in replacing 50\% utility real power. The grid and solar PV each supply 12.5 $\mathrm{KW}$ to load. The consumer takes $12.5 \mathrm{KW}$ of real power and complete $10 \mathrm{KVAR}$ of reactive power from the grid resulting in the reduced power factor to 0.7808 which is not desirable as shown in Fig. 4 (a). Fig. 4 (b) shows the power triangle for the system shown in Fig. 4 (a).

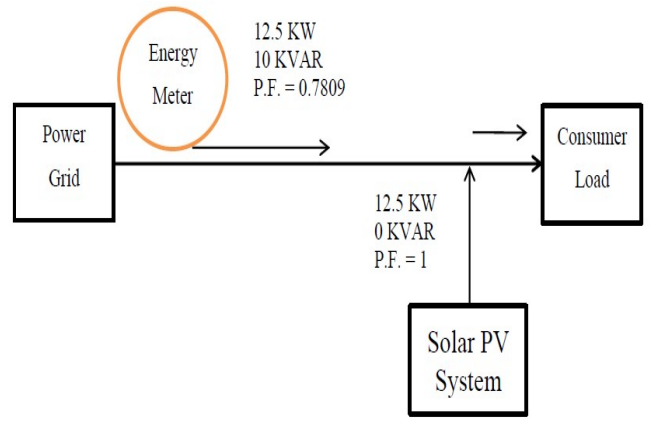

(a)

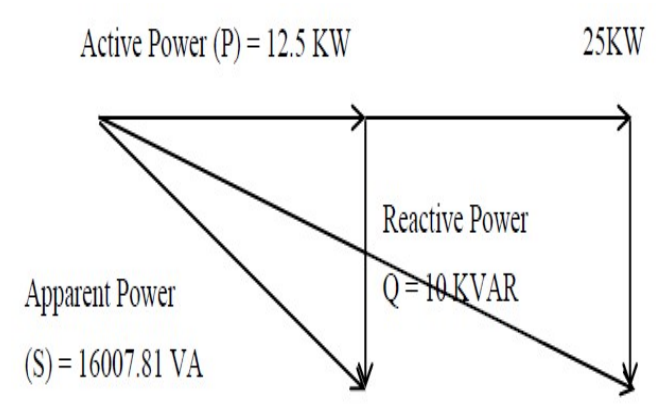

(b)

Fig.4: (a) Schematic of the Distribution System with PV System

(b) Power Triangle

MATLAB Simulation Results:

To overcome the reactive power compensation problem, grid-tied inverter with active power and reactive power control is configured with the instantaneous reactive power theory. When R-L load with $25 \mathrm{KW}$ active power and $10 \mathrm{KVAR}$ reactive power is connected to the grid, the lagging PF of 0.9285 can be seen in Fig. 5. When the grid and the solar PV each supply $12.5 \mathrm{KW}$ to load and complete $10 \mathrm{KVAR}$ of reactive power from the grid resulting in the power factor reduced to 0.7808 which is not desirable is shown in Fig. 6 . With the help of the hysteresis controller and IRPT, improved power factor i.e. reactive power compensation in addition to active power injection can be seen in MATLAB/SIMULINK simulation results as in Fig. 7. MATLAB simulation also carried for different load conditions and results are tabulated in Table 1.

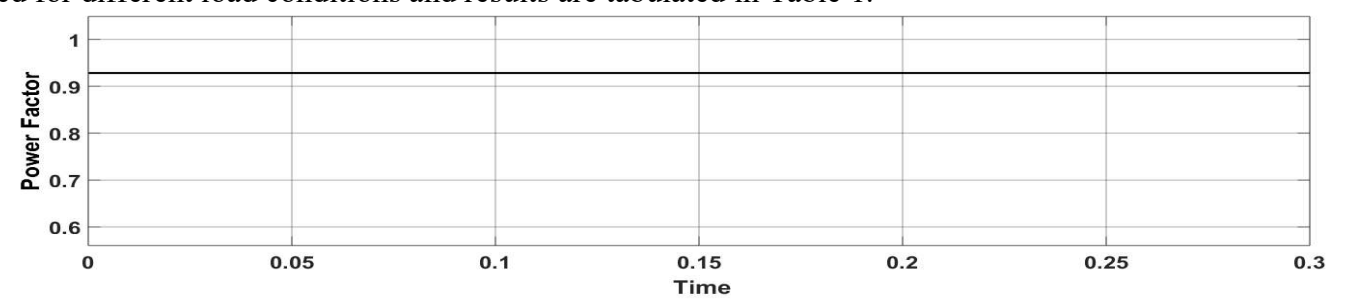

Fig. 5. Power Factor of R-L load when connected to the Grid 


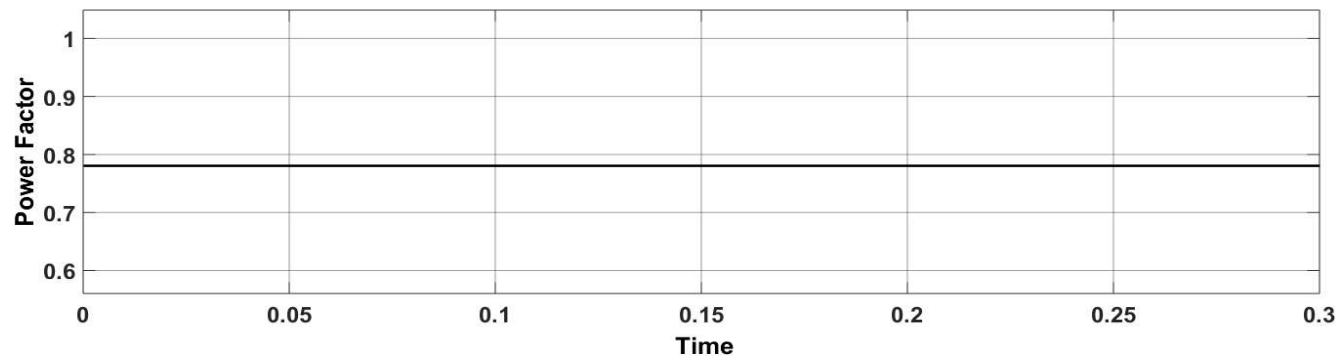

Fig. 6: Power Factor with Grid and the Solar PV System

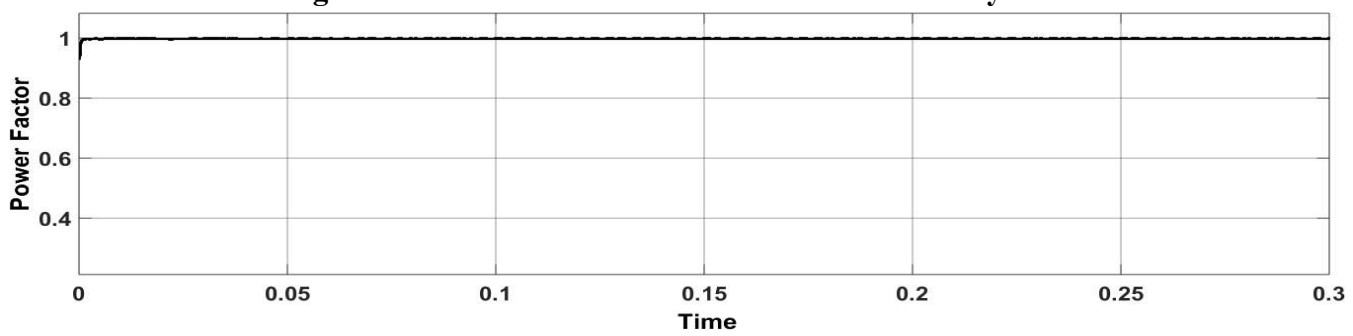

Fig. 7: Improved PF with IRPT and Hysteresis Controller

\begin{tabular}{|c|c|c|}
\hline & $\begin{array}{l}\text { Load P.F. with PV } \\
\text { system }\end{array}$ & $\begin{array}{l}\text { Improved P.F. of Grid connected PV } \\
\text { system with the controller }\end{array}$ \\
\hline $\mathrm{P}=25 \mathrm{KW} ; \mathrm{Q}=18.75 \mathrm{KVAR}$ & 0.8 & 0.978 \\
\hline $\mathrm{P}=12.5 \mathrm{KW} ; \mathrm{Q}=9 \mathrm{KVAR}$ & 0.89 & 0.9864 \\
\hline $\mathrm{P}=20 \mathrm{KW} ; \mathrm{Q}=20 \mathrm{KVAR}$ & 0.7077 & 0.9654 \\
\hline $\mathrm{P}=25 \mathrm{KW} ; \mathrm{Q}=30 \mathrm{KVAR}$ & 0.64 & 0.9256 \\
\hline $\mathrm{P}=30 \mathrm{KW} ; \mathrm{Q}=20 \mathrm{KVAR}$ & 0.832 & 0.97 \\
\hline
\end{tabular}

Table 1: P.F. of Grid Connected PV System for Various Loads

\section{Conclusion}

The grid-connected solar PV system is presented here for active power-sharing as well as the reactive power compensation of the connected load. The solar PV system injects just active power in the system and not reactive power so, the load requirement of the active power from the grid gets reduced and the power factor of the system at PCC decreases. The advancement in power electronics and digital control technology has capacitated the PV systems are now regulated to step up the system operation with improved PQ at PCC. In this paper, control of an existing grid interfacing inverter with instantaneous reactive power theory (IRP) with the hysteresis current controller is presented using MATLAB/Simulink. The grid interfacing inverter in the presented system can be used to reactive power compensation and current harmonics compensation at PCC. The MATLAB simulation study results show the effectiveness and flexibility of the proposed scheme for variable loading conditions also.

\section{References}

1. Karimi, M., Mokhlis, H., Naidu, K., Uddin, S. and Bakar, A.H.A., 2016. Photovoltaic penetration issues and impacts in distribution network-A review. Renewable and Sustainable Energy Reviews, 53, pp.594605.

2. Whaite, S., Grainger, B. and Kwasinski, A., 2015. Power quality in DC power distribution systems and microgrids. Energies, 8(5), pp.4378-4399.

3. Hirsch, A., Parag, Y. and Guerrero, J., 2018. Microgrids: A review of technologies, key drivers, and outstanding issues. Renewable and sustainable Energy reviews, 90, pp.402-411.

4. Hossain, E., Tür, M.R., Padmanaban, S., Ay, S. and Khan, I., 2018. Analysis and mitigation of power quality issues in distributed generation systems using custom power devices. Ieee Access, 6, pp.1681616833.

5. H. Akagi, Y. Kanazawa, and A. Nabae, "Instantaneous reactive power compensator comprising switching devices without energy storage components," IEEE Trans. Ind. Appl., vol. IA-20, no. 3, pp. 625-630, Mar. 1984.

6. Akagi, H., Watanabe, E.H. and Aredes, M., 2017. Instantaneous power theory and applications to power conditioning (Vol. 62). John Wiley \& Sons. 
7. M. Aredes, H. Akagi, E. H. Watanabe, E.V. Salgado, L. F. Encaracao, "Comparison between the p-r and pq-r theories in three phase four wire systems," IEEE Trans. Power Electronics, vol. 24, No. 4, pp. 924-933, Apr. 2009.

8. R. S. Herrera, P. Salmeron, "Instantaneous reactive power theory: A comparative evaluation of different formulations," IEEE Trans. Power Delivery, vol. 22, No.1, Jan. 2007.

9. R. S. Herrera, P. Salmeron, "Instantaneous reactive power theory: A reference in the nonlinear loads compensation," IEEE Trans. on indust. Elect., vol. 56, no. 6, pp. 2015-2022, June 2009.

10. A. Camacho, M. Castilla, J. Miret, J. C. Vasquez, and E. Alarcon-Gallo, "Flexible voltage support control for three-phase distributed generation inverters under grid fault," IEEE Transactions on Industrial Electronics, vol. 60, no. 4, pp. 1429-1441, 2013.

11. Gandoman, F.H., Ahmadi, A., Sharaf, A.M., Siano, P., Pou, J., Hredzak, B. and Agelidis, V.G., 2018. Review of FACTS technologies and applications for power quality in smart grids with renewable energy systems. Renewable and sustainable energy reviews, 82, pp.502-514.

12. P. Rodriguez, A. V. Timbus, R. Teodorescu, M. Liserre, and F. Blaabjerg, "Flexible active power control of distributed power generation systems during grid faults," IEEE Transactions on Industrial Electronics, vol. 54, no. 5, pp. 2583-2592, 2007.

13. R. Teodorescu, M. Liserre, and P. Rodrigues, Grid Converters for Photovoltaic and Wind Power Systems, Wiley-IEEE Press, 2011.

14. Dubey, Ayushi, and Uday Mujumdar. "On the interfacing of photovoltaic system inverter with utility grid." In 2018 International Conference on Smart Electric Drives and Power System (ICSEDPS), pp. 276-280. IEEE, 2018.

15. M. Castilla, J. Miret, J. L. Sosa, J. Matas, and L. G. D. Vicuña, "Grid-fault control scheme for three-phase photovoltaic inverters with adjustable power quality characteristics," IEEE Transactions on Power Electronics, vol. 25, no. 12, pp. 2930-2940, 2010. 